\title{
Dois poemas infantis de Daniil Kharms
}

\section{Aurora F. Bernardini}

"A única coisa que me interessa é o "nonsense": apenas aquilo que não tem sentido prático. A vida só me interessa em suas manifestações absurdas. Heroísmo, páthos, ousadia, ética, higiene, moralidade, ternura e fervor são para mim odiosos, como palavras e como sentimentos. Entretanto eu compreendo perfeitamente e respeito: extase e exultância, inspiração e desespero, paixão e obsessão, devassidão e castidade, tristeza e pena, riso e alegria”.

( Daniil Kharms, 31 de outubro de 1937)

Muito se tem falado do russo Daniil Kharms ( 1905-1942) desde a década de 1970, quando seus escritos começaram a ficar conhecidos no ocidente, e tanto mais hoje quando ele passou a ser considerado precursor de "gigantes" como Ionesco e Beckett. De Ionesco, por suas obras da primeira fase, de um absurdo paradoxal e hilariante que sugerem o de "A cantora careca"; de Beckett, pelo riso estridente e vazio de sua segunda fase, e finalmente de Antonin Artaud e de Fernando Arrabal, pela crueldade explícita de seus textos. Filho muito cuidado de pais amorosos, apesar de idosos, sua infância esteve a cavalo entre o czarismo e o comunismo: do renomado Ginásio Alemão de Peterschule, em São Petersburgo, onde ele nasceu, ( a mãe era de ascendência nobre) à escola comunal soviética, e mais tarde, do Instituto Eletrotécnico de São Petersburgo, ao exílio em Kursk em 1931, da volta a Leningrado à detenção em 1941, à prisão e à morte ( dizem, de fome) em 1942, no Hospital Psiquiátrico de Leningrado.

Até o exílio em 1931, ao qual fora condenado junto com um colega, por suas obras literárias infantis consideradas "antissoviéticas", ele manteve sua alegria de viver , imprimindo seja em poesia, seja em prosa, um tom tão hílare que fazia com que o leitor lesse quanto escrevia com um sorriso nos lábios e as crianças o idolatrassem. Sabe-se, pelas memórias da segunda mulher, Marina Malitch (NORI: 144-145), que "era só ele comparecer ao Palácio dos Pioneiros, às margens do Fontanka, onde ocorriam às matinês dominicais infantis, que as crianças gritavam, pulavam, batiam palmas". Kharms acompanhava a declamação dos poemas que elas sabiam de cor [ como os dois poemas aqui escolhidos, - o "Samovar", particularmente ], com mágicas que as encantavam. Dos artistas que lá se apresentavam, ele era o que tinha mais sucesso. 
Porém, era estranho - diz a sua mulher - pois Daniil, durante sua vida inteira jamais as suportou: detestava as crianças. O dom de suscitar o riso, reforçado pelo seu aspecto (era alto, magro, usava cachimbo à moda de Sherlock Holmes e chapéu de abas), era inato nele; a própria mulher conta que era só Daniil começar a ler um texto seu, tanto infantil quanto adulto, que ela mesma ria sem poder se controlar.

\section{Iván Iványtch, o Samovar}

Iván Iványtch é o samovar,

Barrigudo, o samovar,

De três baldes, samovar

Balançando a água fervente,

Bufando o vapor fervente,

Irado por ser fervente

Despejava da torneira,

Do buraco pra torneira,

$\mathrm{Na}$ tigela, da torneira.

De manhã ele foi chegando,

Ao samovar ele foi chegando,

O tio Piétia foi chegando.

O tio Piétia disse assim:

"Vou bebê-lo" - disse assim, -

"O chá todo" -, disse assim.

Foi chegando ao samovar,

A tia Kátia, ao samovar,

Com um copo, ao samovar.

A tia Kátia disse assim:

“Tá na cara", - disse assim -,

"Também bebo" - disse assim.

Eis que chega o vovozinho,

Muito velho, o vovozinho, 
De chinelo, o vovozinho,

E boceja e diz assim:

"Talvez beba" -, diz assim -,

“Chá talvez", ele diz assim.

Foi chegando a vovozinha,

Muito velha, a vovozinha,

Com bengala, a vovozinha.

Pensa um pouco e diz assim:

"O que bebo?" - diz assim, -

"Bebo chá", - ela diz assim.

De repente vem correndo,

A menina vem correndo,

A netinha vem correndo.

"Vão vertendo!" - diz assim, -

"Uma taça" - diz assim, -

"Bem mais doce", - diz assim.

O cãozinho vem correndo,

O gatinho vem correndo,

Até o chá, eles vêm correndo.

Eles querem água e leite,

Mas fervida, a água e o leite,

E bem quente, a água e o leite.

Já Serioja vem chegando,

Bem sujinho vem chegando,

Atrasado, vem chegando.

"Vão me dando !"- vem dizendo,

"Uma taça", - vem dizendo,

"Bem grandona", - vem dizendo.

Inclinaram, inclinaram, 
Inclinaram o samovar,

Mas por mais que despejassem

Só saiu de lá foi ar.

Espremeram o samovar,

Como fosse uma almofada,

Mas de lá só foi sair

Nada, nada, nada, nada.

Samovar Iván Iványtch!

Sobre a mesa, Ivan Iványtch!

Reluzente, Iván Iványtch!

Água quente ele não serve,

Temporão ele não serve,

Atrasado ele não serve.

Assim é que é.

1928

D. Kharms

Иван Иваныч Самовар

Иван Иваныч Самовар

был пузатый самовар,

трехведёрный самовар.

В нем качался кипяток,

пыхал паром кипяток,

разъярённый кипяток,

лился в чашку через кран,

через дырку прямо в кран,

прямо в чашку через кран.

Утром рано подошел, к самовару подошел, 
дядя Петя подошел.

Дядя Петя говорит:

«Дай-ка выпью,- говорит, выпью чаю», - говорит.

К самовару подошла,

тетя Катя подошла,

со стаканом подошла.

Тетя Катя говорит:

«Я, конечно, - говорит, -

выпью тоже», - говорит.

Вот и дедушка пришел, очень старенький пришел, в туфлях дедушка пришел.

Он зевнул и говорит:

«Выпить разве, - говорит, чаю разве», - говорит.

Тут и бабушка пришла, очень старая пришла, даже с палочкой пришла.

И, подумав, говорит:

«Что ли, выпить, - говорит, что ли, чаю», - говорит

Вдруг девчонка прибежала, к самовару прибежала это внучка прибежала.

«Наливайте! - говорит, чашку чая, - говорит, мне послаще», - говорит.

Тут и Жучка прибежала, 
с кошкой Муркой прибежала,

к самовару прибежала,

чтоб им дали с молоком,

кипяточку с молоком,

с кипяченым молоком.

Вдруг Сережа приходил, неумытый приходил, всех он позже приходил.

«Подавайте! - говорит, чашку чая, - говорит, -

мне побольше», - говорит.

Наклоняли, наклоняли, наклоняли самовар, но оттуда выбивался только пар, пар, пар. Наклоняли самовар, будто шкап, шкап, шкап, но оттуда выходило только кап, кап, кап.

Самовар Иван Иваныч!

На столе Иван Иваныч! Золотой Иван Иваныч! Кипяточку не дает, опоздавшим не дает лежебокам не дает.

$\mathrm{BCE}$

Д. Хармс

1928 


\section{Iván Toporýchkin}

Iván Toporýchkin foi para a caçada,

Seu cão foi com ele, pulando o cercado.

Iván, feito tora, caiu no alagado,

E o poodle no rio caiu feito machado.

Iván Toporýchkin foi para a caçada,

Com ele aos pulinhos o cão feito machado.

Iván, feito tora, caiu no alagado,

E o poodle no rio, pulando o cercado.

Iván Toporýchkin foi para a caçada,

E o cão foi no rio afundando o cercado

Iván, feito tora, pulando o alagado,

E o cão aos pulinhos caiu no machado.

Daniil Kharms

1928

\section{Иван Топорышкин}

Иван Топорышкин пошел на охоту,

с ним пудель пошел, перепрыгнув забор.

Иван, как бревно провалился в болото, а пудель в реке утонул, как топор.

Иван Топорышкин пошел на охоту, 
с ним пудель вприпрыжку пошел, как топор.

Иван повалилась бревном на болото, а пудель в реке перепрыгнул забор.

Иван Топорышкин пошел на охоту, с ним пудель в реке провалился в забор.

Иван как бревно перепрыгнул болото, а пудель вприпрыжку попал на топор.

Даниил Хармс

1928

\section{Referências Bibliográficas}

ANEMONE, Anthony e SCOTTO, Peter ( org. ). I am a phenomenon out of the ordinary-The notebooks, diaries and letters of Daniil Kharms. Boston: Academic Studies Press, 2013 CHARMS , Daniil ( org. trad. e posfácio Rosanna Giaquinta). Casi.Milão: Adelphi, 1990. CHARMS , Daniil ( org. trad. e posfácio Paolo Nori). Disastri.Turim: Einaudi 2003.(NORI: 2003)

JACCARD, Jean-Philippe. Daniil Harms et la fin de l'avant-garde russe.Berna : Peter Lang, 1991.

ЖАККАР, Ж. Ф. Даниил Хармс и конеи русскрово авангарда. São Petersburgo: Академический проект, 1995.

ХАРМС, Даниил. Собрание сочинений. B2T. São Petersburgo: Зебра Е, 2010.

Agradecemos à Editora Kalinka pela cessão dos dois poemas traduzidos, extraídos do livro:

DANIIL KHARMS

PROSA - POESIA -TEATRO VOL.1

“OS SONHOS TEUS VÃO ACABAR CONTIGO”

TRADUÇÃO: AURORA FORNONI BERNARDINI, DANIELA MOUNTIAN E MOISSEI MOUNTIAN POSFÁCIO: AURORA FORNONI BERNARDINI CAPA: FABIO FLAK

COLEÇÃO CONTOS RUSSOS MODERNOS

KALINKA 